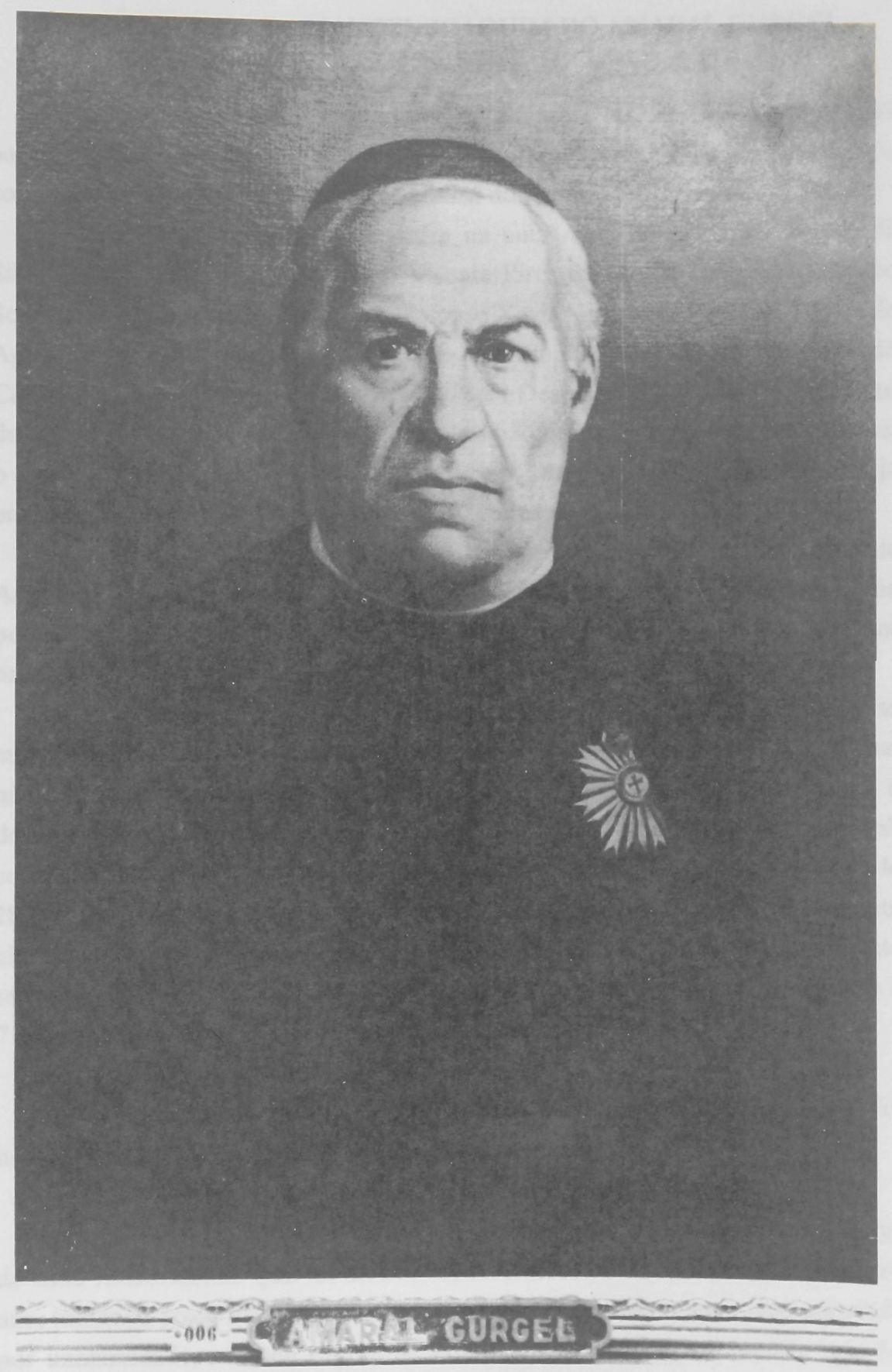





\section{Conselheiro Padre Dr. MANOEL JOAQUIM DO AMARAL GURGEL (1858-1864)}

Nasceu em São Paulo aos 8 de setembro de 1797. Educado por sua parenta e madrinha, D. Maria Polucena do Amaral Gurgel, fora, desde o berço, confiado aos carinhos de D. Beatriz Leoniza do Amaral Gurgel, irmã daquela.

Feito o seu curso de latim na aula régia do professor André da Silva Gomes, onde teve por colegas Vicente Pires da Motta, João Chrispiniano Soares, Joaquim Ignacio Ramalho, Ildefonso Xavier Ferreira, Raphael Tobias de Aguiar, e outros, matriculou-se no curso de teologia, instalado no Convento do Carmo, sob a direção de Frei Antonio do Bom Despacho Mamede. No Convento de São Francisco, freqüentou a aula de filosofia de Frei Francisco Mont'Alverne, o famoso orador sacro, em 1814. Recebeu, em 1816, as ordens de presbítero, já então professor de história eclesiástica no Seminário de São Paulo.

Em 1823, após a queda do ministério Andrada e a dissolução da Assembléia Constituinte, começou o padre Manoel Joaquim a aparecer na política liberal de São Paulo, quando foi deportado para o Rio de Janeiro, por ordem de D. Pedro I.

Instalado o Curso Jurídico de São Paulo, em 1828, nele se matriculou e foi um dos mais destacados da primeira turma acadêmica, o que não obstou a que já então fosse eleito membro do conselho geral da Província e do conselho do Governo. Depois do Ato Adicional, foi deputado provincial, consecutivamente, de 1834 a 1842 e no biênio de 1847 a 1848 . No quatriênio de 1834 a 1837, tomou assento, como suplente, na Câmara dos Deputados. Exerceu, ainda, como vice-presidente, o governo da Província, de 30 de junho a 25 de setembro de 1859; de 22 de outubro a 16 de novembro de 1860; de 14 de maio a 7 de junho de 1861 e de 3 de fevereiro a 7 de março de 1864 .

Recebeu o título de Conselheiro.

Por carta imperial de 6 de julho de 1829, aprovado em concurso, foi nomeado lente de filosofia do Curso Anexo.

Recebeu o grau de bacharel em 1832.

A 1o de fevereiro de 1833, passou a exercer, interinamente, o cargo de lente substituto, no qual foi efetivado por decreto de 12 de outubro do mesmo ano, tomando posse em 15 de novembro. Tendo defendido teses e sido aprovado por unanimidade, recebeu o grau de doutor em 1834, e nesse mesmo ano foi 
nomeado lente catedrático, por decreto de 14 de janeiro. Tomou posse a 27 de fevereiro da primeira cadeira do segundo ano.

Com a demissão do senador Vergueiro, em 1842, ficou vaga, e por dilatado tempo, a diretoria do curso jurídico, uma vez que, nomeado diretor naquela data, o Visconde de Goyana jamais tomou posse do cargo; e essa acefalia durou por mais de quinze anos. Foi o Padre Manoel Joaquim, em 1837, nomeado diretor interino, exercendo esse cargo até 1838. Por decreto de 10 de dezembro de 1857 foi nomeado diretor efetivo da Faculdade de Direito, como passou a denominar-se o curso jurídico, pelo Decreto n. 714, de 19 de setembro de 1853 , tomando posse em $1^{\circ}$ de março de 1858. Jubilou-se por decreto de 18 de maio de 1858 , no cargo de lente.

Jamais, segundo o testemunho de Almeida Nogueira, teve a Academia diretor que melhor conciliasse com o respeito devido ao cargo a simpatia dos estudantes, a estima dos lentes e professores e a dedicação dos funcionários seus subordinados na hierarquia administrativa.

Faleceu o Conselheiro Padre Dr. Manoel Joaquim do Amaral Gurgel em 15 de novembro de 1864, contando 67 anos de idade. Seu nome foi dado à rua que liga o Largo do Arouche à Rua da Consolação, na cidade de São Paulo 